\title{
Characteristics and classification of the quality and productive standards of the mombaça grass under a livestock-forest system or full sun
}

\author{
Comportamento e classificação dos padrões qualitativos e \\ produtivos do capim mombaça em sistema sivipastoril e pleno sol
}

\author{
Leonardo Bernardes Taverny de Oliveira ${ }^{1 *}$; Antonio Clementino dos Santos ${ }^{2}$; \\ Hugo Mariano Rodrigues de Oliveira ${ }^{3}$; Tiago Barbalho André ${ }^{3}$; Durval Nolasco das \\ Neves Neto ${ }^{3}$; Otacílio Silveira Júnior ${ }^{4}$
}

\begin{abstract}
The objective of this study is to identify qualitative and productive changes in Mombasa grass under a livestock-forest system or full sun and to classify the variables that are most relevant for evaluating the qualitative performance of these systems. The experiments were conducted in shade areas, with four replications for each of the 12 treatments, including four growth cycles and three levels of shading in Mombasa grass, totaling 48 experimental units. Calcium $(\mathrm{Ca})$, magnesium $(\mathrm{Mg})$, potassium $(\mathrm{K})$, phosphorus $(\mathrm{P})$, nitrogen $(\mathrm{N})$ and dry mass production $(\mathrm{DMP})\left(\mathrm{kg} \mathrm{ha}^{-1}\right)$ were used as discriminatory variables for the shading groups. The levels of nutrients and shading in Mombaça grass were classified using Fisher multivariate discriminant analysis (FMDA). The FDMA indicated that $\mathrm{Mg}, \mathrm{K}, \mathrm{P}, \mathrm{N}$, and DMP formed a discriminant function. However, DMP was the least important variable for identifying the groups. Five groups were pre-defined before FDMA: MFS 2 (Mombasa grass in full sun in the second cycle), MFS 6 (Mombasa grass in full sun in the sixth cycle), MFS 7 (Mombasa grass in full sun in the seventh cycle), M25 4 (Mombasa grass at 25\% shading in the fourth cycle), and M25 7 (Mombasa grass at $25 \%$ shading in the seventh cycle). The results indicate that $\mathrm{Mg}, \mathrm{P}, \mathrm{K}$, and $\mathrm{N}$ are helpful for identifying new genotypes of plants grown on shading conditions because of the responsiveness and stability of these elements to environmental changes.
\end{abstract}

Key words: Cycles. Macronutrients. Multivariate. Panicum maximum.

\section{Resumo}

Objetivou com este estudo identificar as alterações qualitativas e produtivas do capim Mombaça em sistema silvipastoril e pleno sol, e classificar as variáveis mais estratégicas para avaliação do seu desempenho qualitativo. O ensaio foi alocado em faixas de sombreamento, com quatro repetições para cada um dos 12 tratamentos - quatro ciclos e três porcentagens de sombreamento, em capim Mombaça, totalizando 48 unidades experimentais. Foram usados os macroelementos: cálcio $(\mathrm{Ca})$, magnésio $(\mathrm{Mg})$, potássio $(\mathrm{K})$, fósforo $(\mathrm{P})$ e nitrogênio $(\mathrm{N})$ e Produção de massa seca $(\mathrm{PMS})\left(\mathrm{kg} \mathrm{ha}^{-1}\right)$ como variáveis de

1 Bolsista do Programa Nacional de Pós-Doutorado, PNPD/CAPES, Programa de Pós-Graduação em Ciência Animal Tropical, Universidade Federal do Tocantins, UFT, TO, Brasil. E-mail: tavernyzoot@yahoo.com.br

2 Prof., Universidade Federal do Tocantins, UFT, Araguaína, TO, Brasil. Bolsista de Produtividade, CNPq. E-mail: clementino@ uft.edu.br

3 Prof., Instituo Tocantinense Presidente Antônio Carlos, UNITPAC, Araguaína, TO, Brasil. E-mail: druval.nolasco@gmail.com

4 Técnico Laboratório de Solos, Instituto Federal do Tocantins, IFTO, Dianópolis, TO, Brasil. E-mail: otaciliosilveira@gmail.com

* Author for correspondence 
discriminação de grupos de sombreamento. A classificação das variáveis e dos níveis de sombreamento enriquecido com mombaça, procedeu-se por meio da Análise Multivariada Discriminante de Fisher (ADF). Foi possível com o auxílio da ADF identificar as variáveis Mg, K, P, N e PMS como significativas para formação da função discriminante. Entretanto, o teor de PMS foi o menos relevante para identificação dos grupos. Cinco grupos foram pré-definidos antes da análise discriminante, MSP $2^{\circ}$ (Mombaça pleno sol $2^{\circ}$ ciclo), MSP $6^{\circ}$ (Mombaça pleno sol $6^{\circ}$ ciclo), MSP $7^{\circ}$ (Mombaça pleno sol $7^{\circ}$ ciclo), M25 $4^{\circ}$ (Mombaça 25\% $4^{\circ}$ ciclo) e M $257^{\circ}$ (Mombaça 25\% $7^{\circ}$ ciclo). Para auxiliar na busca de novos genótipos considerando a concentração de nutrientes em estudos sobre condições de sombreamento, os elementos $\mathrm{Mg}, \mathrm{P}, \mathrm{K}$ e $\mathrm{N}$ oferecem grande auxílio pela sua responsividade e estabilidade as oscilações ambientais.

Palavras-chave: Ciclos. Macronutrientes. Multivariada. Panicum maximum.

\section{Introduction}

Nutrients are vital for plant survival, tissue composition, and dry matter production (DMP). Variations in the composition of each element in plant tissues are intrinsic to each plant genotype and climatic conditions.

The composition of elements in plant tissues is controlled by abiotic factors that affect the microclimate, including soil moisture and nutrient solubility for a longer period (YADAV et al., 2014), allowing plants to improve physiological processes, ensuring that the concentration of nutrients in the leaves is closer to the concentration desired for plant and animal production.

Some forage plants with high resilience to environmental variations may present changes in the nutrient profile even in cases in which their morphological and growth characteristics are affected by shading conditions. Araújo Filho et al. (2002) evaluated the effect of manipulating the woody vegetation in the Caatinga on the enrichment of Poaceae pastures and observed that a tree canopy cover of $32-39 \%$ allowed establishing productive levels similar to those of treatments in full sun.

The application of livestock systems to forests provides economic and environmental sustainability and allows the joint exploration of livestock and forests for a longer period (FERREIRA, 2005; ALMEIDA et al., 2015) without profoundly affecting the ecological relations present in native environments and providing high-quality biomass.
However, livestock-forest systems are based on forage exploitation, which in turn is based on photosynthesis and the presence of structural plant components that ensure proper physiological functioning. In this sense, nutrients are an integral part of photosynthetic molecules, including magnesium and nitrogen for chlorophyll production, phosphorus for energy conservation, and potassium for the regulation of osmotic pressure, stomatal activity, and enzyme activation.

The increase in the nutrient content in the soil may be closely associated with shading because of the mineralization of litter originated from the tree canopy. Therefore, shading may directly affect the mineral composition and the internal and morphophysiological structure of plants. A more pronounced effect occurs in cases in which there is limited availability of primary macronutrients, which affects anatomical and functional characteristics, as well as variables that affect the nutrient absorption profile of forage plants (BASSO et al., 2014; LAJÚS et al., 2014).

One of the elements that more strongly affect the structure and physiological functioning of plants is nitrogen (N) (MONTEIRO et al., 2014). Several studies demonstrated the productive and qualitative response of forage plants to the limited availability of N (BASSO et al., 2014; LAJÚS et al., 2014; VILMO et al., 2011). The increase in the concentration of $\mathrm{N}$ and protein, changes in the amount of lignin with the increase in the supply of N (SILVEIRA JUNIOR et al., 2017) and shade 
(GOBBI et al., 2010), as well as changes in plant tissues used in the nutrition of ruminants, including increased thickness of the mesenchyma and decreased thickness of the sclerenchyma (GABBI et al., 2011), cause a quantitative and qualitative increase in forage mass.

Each macronutrient has a specific role, from the development of the rhizosphere to the functional composition of the plant, and becomes available by absorption or translocation. Some ions may act antagonistically to each other, as is the case of $\mathrm{K}$ and $\mathrm{Mg}$ (RAO et al., 1987). In this respect, high concentrations of $\mathrm{K}$ in the soil may limit the absorption of $\mathrm{Mg}$ ions, whereas $\mathrm{K}$ enhances the absorption of nitrate ions (MEURER, 2006).

$\mathrm{Ca}, \mathrm{Mg}$, and $\mathrm{K}$ ions compete for the same binding sites. Therefore, the concentration of each element can be affected by the concentration of the others (RAO et al., 1987) and by changes in abiotic factors such as shading. Although the concentration of $\mathrm{Ca}$ is not directly correlated with shading (ERIKSEN; WHITINEY, 1982), Ca levels may increase (ALMEIDA et al., 2015) via nutrient cycling (SELLE, 2007) and litter mineralization (MONTEIRO et al., 2014; CIOTTA et al., 2004). However, the concentrations of $\mathrm{K}, \mathrm{Mg}, \mathrm{P}$, and $\mathrm{N}$ may change in plant leaves depending on environmental conditions (COLE; RAPP, 1980), including the level of fertilization (MONTEIRO et al., 2014) and shading (ALMEIDA et al., 2015).

Investigating the productive response and nutrient composition of forage plants can subsidize scientific advances on new genotypes for shaded environments by analyzing elements that produce desirable characteristics within the same species, seeking to determine the nutrient levels and biomass production necessary for increasing animal productivity (SILVEIRA JÚNIOR et al., 2017).

The nutrient levels of plants are inserted in the context of animal nutrition because nutrients act independently in each organism for the joint benefit of plants and animals. The nutritional demand of ruminants can be affected by the adequate nutritional status of plants. Therefore, it is necessary to classify different plant groups by analyzing variables that are important for forming a discriminant function (CAMPOS, 2012).

The objective of this study is to identify qualitative and productive changes in Mombasa grass under a livestock-forest system or full sun, and to identify the variables that are more relevant for assessing the performance of these systems.

\section{Material and Methods}

The experiment was conducted at the School of Veterinary Medicine and Animal Science (Escola de Medicina Veterinária e Zootecnia-EMVZ) of the Federal University of Tocantins, in a livestockforest system of thinned forest on a flat topography ( $2 \%$ slope). The climate of the region is Aw (hot and humid) according to Köppen classification, with rainfall from October to May, mean annual rainfall of $1,800 \mathrm{~mm}$, and mean temperature of $28^{\circ} \mathrm{C}$. The soil was classified as Quartzarenic Neosol of sandy texture and was subjected to chemical analysis at a depth of 0-20 cm (Table 1). 
Table 1. Chemical characterization of the soil at the beginning of the experiment implantation, preceding the first cycle.

\begin{tabular}{lcccccccccc}
\hline & $\mathrm{pH}$ & $\mathrm{Ca}^{2+}$ & $\mathrm{Mg}^{2+}$ & $\mathrm{Al}^{3+}$ & $\mathrm{H}+\mathrm{Al}$ & $\mathrm{K}^{+}$ & $\mathrm{P}$ & $\mathrm{MO}$ & $\mathrm{CTC}$ & $\mathrm{V}$ \\
\hline & $\mathrm{CaCl} 2$ & $--------------\mathrm{cmol}_{\mathrm{c}} \mathrm{dm}^{-3}-------------------$ & $---\mathrm{mgdm}^{-3}-------$ & $\mathrm{cmol}_{\mathrm{c}} \mathrm{dm}^{-3}$ & $\%$ \\
\hline MSP & 4,57 & 0,86 & 0,57 & 0,42 & 4,64 & 0,009 & 2,80 & 8,04 & 6,08 & 23,70 \\
M25 & 4,17 & 1,13 & 0,90 & 0,74 & 5,22 & 0,017 & 2,79 & 11,73 & 7,27 & 28,17 \\
M50 & 3,97 & 0,78 & 0,78 & 1,10 & 4,76 & 0,013 & 3,13 & 12,51 & 6,35 & 24,95 \\
\hline
\end{tabular}

Soil analysis in the depth of 0-20 cm, in Neosol Quartzarênico Ortico typical. MSP: Mombasa full sun; M25: Mombasa 25\% shade; M50: Mombasa 50\% shade. V: base saturation. MO: organic matte.

The meteorological data on rainfall and climatological station of Araguaína, located at mean temperature were obtained from the main EMVZ (Figure 1).

Figure 1. Monthly precipitation $(\mathrm{mm})$, average temperature $\left({ }^{\circ} \mathrm{C}\right)$ from january 2014 to december 2014 . Full bars: precipitation; gray line: temperature.

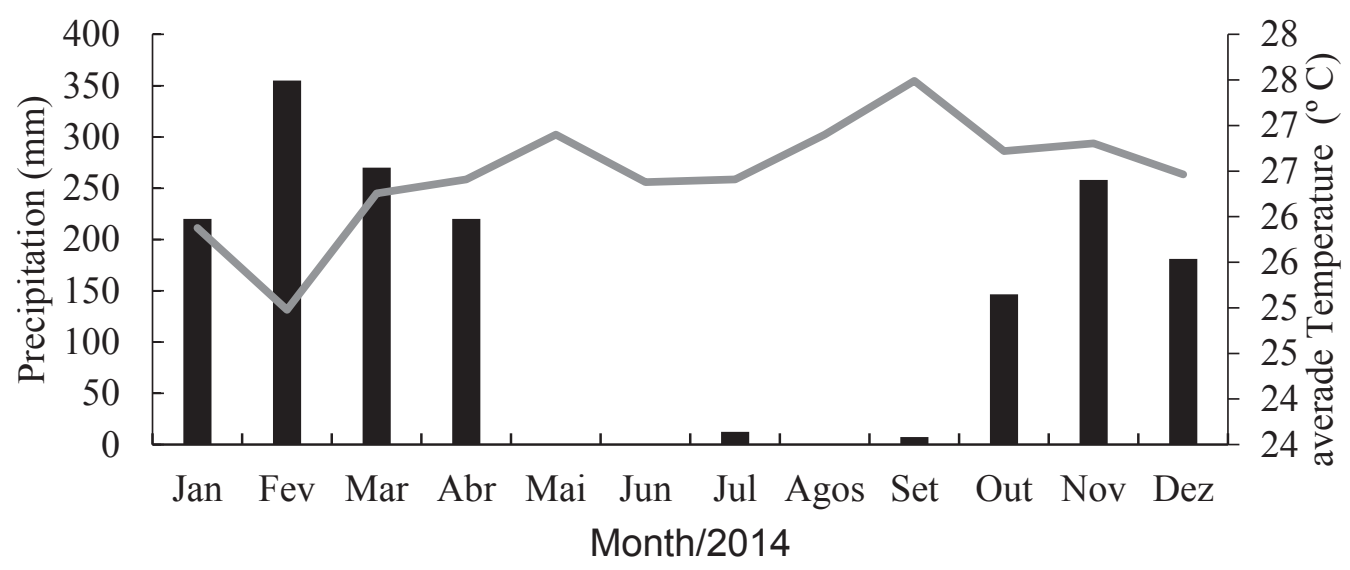

The experiments were conducted in shade areas, with four replicates for each of the 12 treatments, including four growth cycles and three levels of shading, totaling 48 experimental units.

The first analysis of the forest was conducted in October 2009, adopting as a criterion of thinning a level of shading of $0 \%, 25 \%$, and $50 \%$ of light transmission through the canopy, and the measurements were revised in June 2012 using a lux meter. Thinning was systematically performed by removing trees with denser canopies and monitoring the light input until it reached the desired level.

After the management of the trees, limestone was applied in October 2013, in the order of $800 \mathrm{~kg}$ ha-1, $50 \mathrm{~kg}$ of $\mathrm{P}_{2} \mathrm{O}_{5} \mathrm{~kg} \mathrm{ha}^{-1}$, and $60 \mathrm{~kg}$ of $\mathrm{K}_{2} \mathrm{O} \mathrm{ha}{ }^{-1}$, followed by the planting of forage grass. After the standard harvest performed in December 2013, we expected the appearance of three leaves in the grass after grazing, and the livestock was transferred to $2,250 \mathrm{~m}^{2}$ pens. On the third day after removing the animals from the pens, nitrogen fertilization was performed with $40 \mathrm{~kg}$ of $\mathrm{N} \mathrm{ha}^{-1}$ cycle $^{-1}$. The evaluations began in January 2014, after a standard harvest using a brush cutter at the height of $20 \mathrm{~cm}$ from the soil surface.

Leaf samples were collected in four growth cycles, before the entry of the animals into the pens. Each cycle was completed with the appearance 
of three expanded leaves in the grass at 22 to 25 days after grazing. The first cycle in 2014 was excluded from the analysis because the uniform harvesting achieved with the brush cutter affected the structural development of the canopy and was used to standardize the effectiveness of grazing. In the third and fifth cycles, there were infestations by spittlebugs. Therefore, the evaluation started from the second cycle (February), continuing to the fourth cycle (April and May), sixth cycle (September and October), and seventh cycle (October and November).

\section{Chemical analysis of plant tissues}

The samples collected from each cycle were harvested and dried in a forced ventilation oven at $55{ }^{\circ} \mathrm{C}$ for 48 hours, then milled in a Willey mill (EMBRAPA, 2005). The following elements were analyzed in the samples sieved through a $1.0 \mathrm{~mm}$ sieve: $\mathrm{Ca}, \mathrm{Mg}, \mathrm{K}$, and $\mathrm{P}$. These elements were decomposed using a dry method and were diluted in hydrochloric acid (NOGUEIRA; SOUZA, 2005). Half a gram of each sample was weighed and transferred to an oven for gradual burning for 6 hours until the samples reached $500{ }^{\circ} \mathrm{C}$. Ca and $\mathrm{Mg}$ were quantified by complexation with ethylenediaminetetraacetic acid (EDTA- $\left.\mathrm{Na}_{2}\right)$.

Was quantified using the colorimetric method of molybdenum blue $\left(\mathrm{H}_{2} \mathrm{MoO}_{4}\right)$ by absorption spectrophotometry. $\mathrm{K}$ was quantified by flame photometry. Total nitrogen was determined via the quantification of ammoniacal nitrogen by wet decomposition according to the semi-micro Kjeldahl method (NOGUEIRA; SOUZA, 2005).

$$
\mathrm{NT}=(\mathrm{Va}-\mathrm{Vb}) \times \mathrm{F} \times 0,1 \times 0,014 \times 100
$$

$\mathrm{P} 1$

NT: total nitrogen

F: correction factor for hydrochloric acid 0,01 mol L-1
$\mathrm{Va}$ - volume of the hydrochloric acid solution spent in the titration of the sample, in milliliters.

$\mathrm{Vb}$ - volume of the hydrochloric acid solution used in the white titration, in milliliters.

P1: forage mass.

\section{Quantification of dry matter}

The forage samples were collected using a 0.75 $\mathrm{m}^{2}(1.50 \times 0.5 \mathrm{~m})$ metal frame, cut at a height of 10 $\mathrm{cm}$ from the soil surface, transferred to plastic bags, and sent to the laboratory, where the total fresh matter was weighed. An aliquot of the fresh matter was dried in a forced-ventilation oven at $55^{\circ} \mathrm{C}$ for 72 hours to determine the pre-dried matter. After quantifying the pre-dried matter, the sample was processed in a Wiley-type mill using a 1-mm sieve and dried at $105^{\circ} \mathrm{C}$ (SILVA; QUEIROZ, 2002).

\section{Statistical analysis}

Before the multivariate discriminant analysis, an exploratory analysis of the data was conducted for understanding the specific characteristics of the variables in group segregation. The variables most relevant for selecting forage grass were determined by organizing the data into a matrix for later Fisher discriminant analysis, and this analysis was useful for classifying and separating groups using the function obtained with the coefficients. The results of the multivariate analysis were analyzed using the statistical software STATISTIC version 8.1.

\section{Results and Discussion}

The concentrations of the elements in Mombasa grass in full sun (MFS), 25\% shade (M25), and 50\% shade (M50), and their variability at the respective cycles 2, 4, 6, and 7 are shown in Figure 2.

In the second cycle, the levels of $\mathrm{Ca}, \mathrm{K}$, and $\mathrm{N}$ were similar between the treatments, in contrast to the levels of $\mathrm{P}$ and $\mathrm{Mg}$ (Figure 2). In the second 
cycle, the nutrient concentration provided by the recent and homogeneous fertilization between the treatments and the water availability favored the increased use of nutrients by the forage plants.

The $\mathrm{Ca}$ levels in the second cycle remained unchanged between the different shade levels, and treatment in full sun maintained the Ca levels stable between the second and sixth cycles. Treatments at $25 \%$ and $50 \%$ shading significantly decreased $\mathrm{Ca}$ concentrations in periods of water scarcity (fourth and sixth cycles). However, $\mathrm{Ca}$ concentrations were recovered in the seventh cycle $(0.92 \%$ and $0.99 \%$, respectively) and were significantly increased in Mombasa grass grown in full sun (1.70\%). Almeida et al. (2015) evaluated the concentration of nutrients in leaves of forage legumes and found results similar to those of the present study, with an increase in the concentration of $\mathrm{P}$ and $\mathrm{Ca}$ in periods of higher water availability and higher shading (70\%). Shading may have affected $\mathrm{Ca}$ concentration in leaves because of the decrease in the light supply considering that the participation of $\mathrm{Ca}$ in the formation of the cell wall is proportional to the wall thickness (CASTRO et al., 2001), which may result in a higher concentration of $\mathrm{Ca}$ in forage plants grown in full sun (ALMEIDA et al., 2015). Ca is an important stabilizer of membranes and organelles and is a structural component of the cell wall in middle lamellae (TAIZ; ZEIGER, 2009), which indicates a positive correlation between the cell wall and $\mathrm{Ca}$ content, as observed in forage plants grown in full sun.

Among the factors that affect $\mathrm{Ca}$ concentration in plants, the synthesis of calcium oxalate, which is very common in cultivars of Panicum maximum, is strongly correlated with the low concentration of nitrates in the leaves, resulting in the formation and accumulation of crystals in cell vacuoles (VITTI et al., 2006). Shaded plants tend to have higher concentrations of $\mathrm{NO}_{3}^{-}$in the leaves and may present decreased levels of molecular calcium in tissues. Many cell types require additional levels of calcium ions to maintain the integrity of cytoplasmic organelles (TAIZ; ZEIGER, 2002; SCARDELATO et al., 2013).

$\mathrm{N}$ levels remained stable between cycles in M50 (Figure 2), indicating a more homogeneous environment. However, N levels were highly variable between the growth cycles for treatments M25 and MFS. However, the N contents were higher at M25 from the fourth to the seventh cycle. Under normal conditions, the $\mathrm{N}$ absorbed by plants participates in the synthesis of proteins and enzymes while maintaining the physiological functions active (LAJÚS et al., 2014).

The assimilation of $\mathrm{CO}_{2}$ depends on the rubisco activity, which in turn is stimulated by temperature and solar radiation (TAIZ; ZEIGER, 2009). Shading limits the assimilation of carbon, which is an integral part of the structure of molecules in cell walls (lignin, cellulose, and hemicellulose), which compete for space in cells (LARA; PEDREIRA, 2011). In contrast, moderate shading has nutritional benefits to plants because shading requires $\mathrm{N}$ for tissues to improve the photosynthetic efficiency, resulting in a higher concentration of $\mathrm{N}$ in the $25 \%$ shade treatment.

The contents of $\mathrm{K}$ and $\mathrm{N}$ (Figure 2) were similar in the second cycle. Treatment M50 maintained the levels of $\mathrm{K}$ and $\mathrm{N}$ in the study period, and M25 presented higher levels of these nutrients in the second and fourth cycles, and the levels were similar to those of the other treatments in the seventh cycle. In contrast, there was a significant decrease in the concentration of these nutrients in the fourth and sixth cycles in the treatment in full sun. 
Figure 2. Mean values and their respective confidence intervals for nutrients: $\mathrm{Ca}, \mathrm{Mg}, \mathrm{K}$ and $\mathrm{P}$ of the aerial part of the Mombasa grass under 0, 25\% and 50\% of shade. SP: Mombasa in full sun; 25\%: Mombasa at 25\% shade; 50\%: Mombasa at 50\% shade. Calculation of measure repeated in time. Bars denote confidence interval. Shad.: Shading.
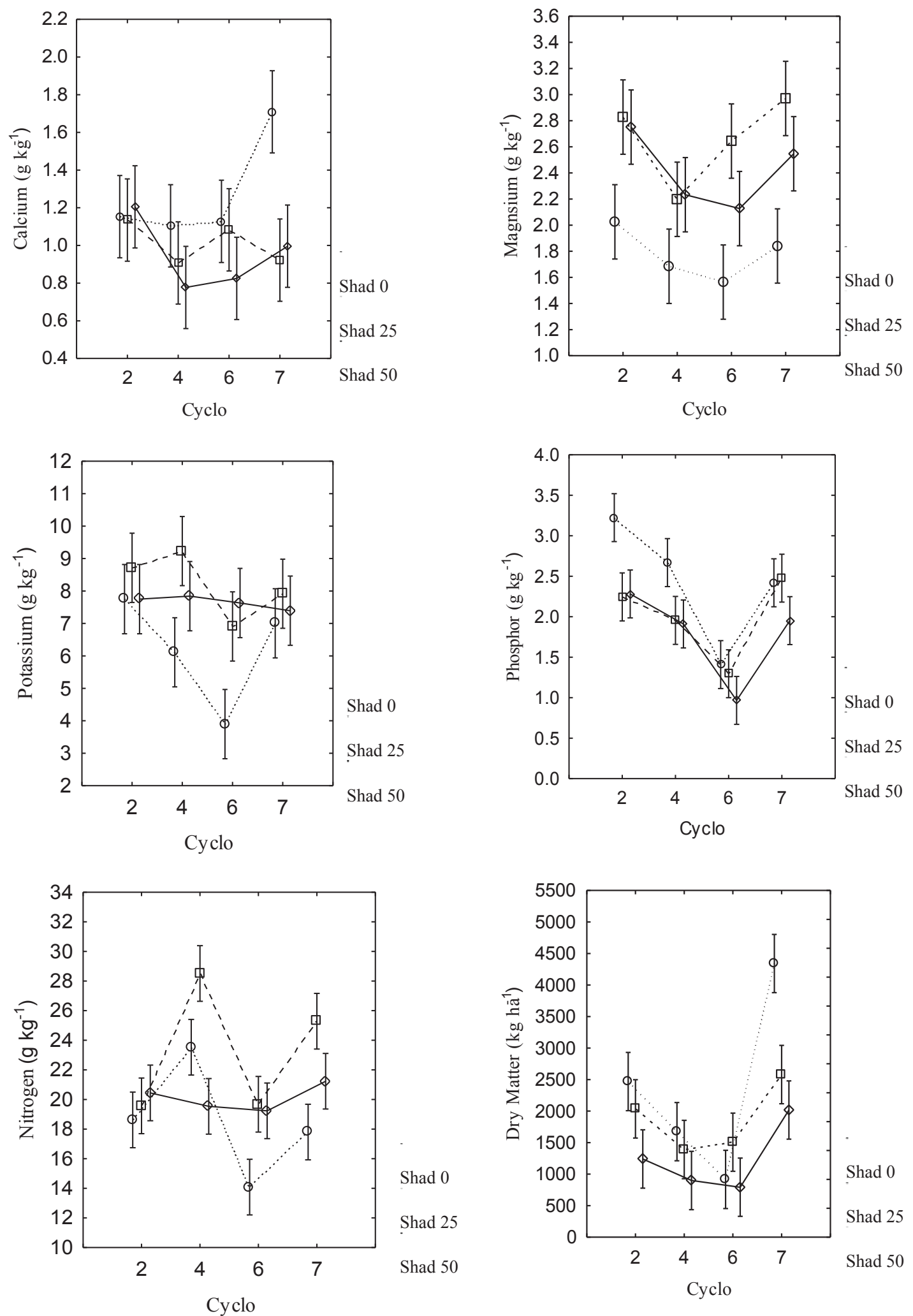
Taking into account the NRC (2000) requirements of $\mathrm{K}$ in growing and mature beef cattle, corresponding to $0.6 \%$ of dry matter (DM) $\left(6 \mathrm{~g} \mathrm{~kg}^{-1} \mathrm{day}^{-1}\right)$, shade of $25 \%$ and $50 \%$ (Figure 2) would meet the demand for this nutrient throughout the year, and the concentrations were 9.3 to 7.1 $\mathrm{g} \mathrm{kg}^{-1}$ day $^{-1}$ in the two treatments, respectively. However, in the treatment in full sun, the supply of $\mathrm{K}$ would be limited during the dry season, between cycles 4 and 6.

$\mathrm{Mg}$ is essential to the ecophysiology of plants because it is part of the molecular structure of chlorophyll and therefore is essential for the photosynthetic efficiency. Shaded areas allow the plants from these environments to conserve $\mathrm{Mg}$ in the leaves (VITTI et al., 2006), although Mg levels vary and its participation in forage leaves is decreased in periods of low precipitation (Figure 2). $\mathrm{Mg}$ was the only element whose concentration remained higher in the shaded treatments (2.2 to 3.1 $\left.\mathrm{g} \mathrm{kg}^{-1}\right)$ compared to plants grown in full sun $(2.10$ to $1.59 \mathrm{~g} \mathrm{~kg}^{-1}$ ) since the second cycle. The adaptive capacity of forage species to shading allowed shaded plants to have higher concentrations of $\mathrm{Mg}$ in the leaves because of the higher synthesis of chlorophyll, which is responsible for photochemical processes in the plant.

Nutrient concentrations did not vary significantly in treatment M25, with the exception of $\mathrm{K}$, which was less affected by water shortage in cycles 4 and 6 (rain-dry transition) and returned to the initial concentration (cycle 2), demonstrating that it is less sensitive to climatic variations than to full sun (Figure 2). The livestock-forest system at $25 \%$ shading allowed more light input to the soil, causing larger variations in litter temperature, helping organisms to increase the rate of degradation of organic matter, resulting in higher release of nutrients to the rhizosphere and enhanced nutrient cycling (MONTEIRO et al., 2014), supplying the plants with a higher concentration of nutrients, which affected the nutrient profile in the aerial part of the plants (COELHO et al., 2014).
Of the analyzed variables, the levels of $\mathrm{Ca}$ and dry mass (kg ha-1) were different from those of the other elements ( $\mathrm{N}, \mathrm{P}, \mathrm{K}$, and $\mathrm{Mg}$ ) in the last cycle and were higher at the end of the 12-month period. However, from the sixth cycle, which is the most critical period for plant growth, plant productivity and the concentration of all elements at $25 \%$ shading were higher in full sun.

Castro et al. (2001) measured the concentration of nutrients in six grass species in $0 \%, 30 \%$, and $60 \%$ shading and observed an increase in the contents of $\mathrm{Mg}, \mathrm{K}$, and $\mathrm{P}$ in the tissue of Poaceae plants under shading. In addition, only Ca levels were different from those of the present study.

The discriminant analysis allowed separating the groups using the original variables (Table 2). However, the discriminant force of each variable depends on the variability and stability of the intragroup and intergroup data, which may result in discriminant functions of higher classificatory accuracy. Although all the evaluated variables formed discriminant functions, $\mathrm{P}, \mathrm{Mg}$, and $\mathrm{N}$ were more representative for classifying forage quality in order of decreasing magnitude. The first two discriminant factors accumulated $79 \%$ of the explained variability, and the generated model could explain $97 \%$ of the analyzed samples.

The discriminant functions shown below are necessary for classifying the groups. The first function classifies the treatments for $\mathrm{P}$ and $\mathrm{N}$, the second function classifies the treatments for $\mathrm{Mg}$, and the third function classifies the treatments for $\mathrm{K}$.

Discriminant function 1: $19,86+\left(-0,97 \mathrm{Mg}^{2+}\right)+(-$ $\left.0,26 \mathrm{~K}^{+}\right)+(-2,84 \mathrm{P})+(-0,36 \mathrm{~N})+(-0,0009 \mathrm{MS})$.

Discriminant function 2: $3,21+\left(-2,82 \mathrm{Mg}^{2+}\right)+(-$ $\left.0,31 \mathrm{~K}^{+}\right)+(1,36 \mathrm{P})+(0,20 \mathrm{~N})+(-0,0007 \mathrm{MS})$.

Discriminant function $3:-0,40+\left(1,32 \mathrm{Mg}^{2+}\right)+(-$ $\left.0,81 \mathrm{~K}^{+}\right)+(0,01 \mathrm{P})+(0,14 \mathrm{~N})+(-0,0001 \mathrm{MS})$. 
Table 2. Coefficients of discriminant functions.

\begin{tabular}{|c|c|c|c|c|c|c|}
\hline & $\mathrm{CP}$ & $\mathrm{CNP}$ & $\mathrm{CP}$ & $\mathrm{CNP}$ & CP & $\mathrm{CNP}$ \\
\hline Variáveis & \multicolumn{2}{|c|}{ Discriminant 1} & \multicolumn{2}{|c|}{ Discriminant 2} & \multicolumn{2}{|c|}{ Discriminant 3} \\
\hline $\mathrm{Mg}^{*}$ & $-0,27$ & $-0,97$ & $-0,79$ & $-2,82$ & 0,37 & 1,32 \\
\hline $\mathrm{K}^{*}$ & $-0,28$ & $-0,26$ & $-0,33$ & $-0,31$ & $-0,85$ & $-0,81$ \\
\hline $\mathrm{P}^{* *}$ & $-0,83$ & $-2,84$ & 0,39 & 1,36 & 0,003 & 0,01 \\
\hline $\mathrm{N}^{* *}$ & $-0,67$ & $-0,36$ & 0,37 & 0,20 & 0,27 & 0,14 \\
\hline MS* & $-0,45$ & $-0,0009$ & $-0,36$ & $-0,0007$ & 0,066 & 0,0001 \\
\hline Constant & - & 19,40 & - & 3,21 & - & $-0,40$ \\
\hline Eigenvalue & 13,58 & 13,58 & 3,46 & 3,46 & 0,64 & 0,64 \\
\hline Accumulated ratio & 0,53 & 0,53 & 0,66 & 0,66 & 0,69 & 0,69 \\
\hline
\end{tabular}

* Significant at 5\% probability. ** Significant at 1\% probability. CP: Standardized coefficient (Correlation between discriminant variable and original variable). CNP: Non-standardized coefficient. Ca, did not present normal distribution in the analysis of Shapiro Wilks.

The higher was the standardized coefficients, the stronger was the relationship between the variable and the discriminant function. Therefore, it is recommended to use the most discriminant variable that is aligned to the best correlated discriminant function. In this case, P, N, and DM are associated with the first function, $\mathrm{Mg}$ is associated with the second function, and $\mathrm{K}$ is associated with the third function.

Shoot DM had a low correlation with the three discriminant functions, which limits the role of this variable in making distinctions between the groups (Table 2).
The values of the discriminant functions are shown in Table 3. Considering that the score values represent the magnitude of the original data in most cases, the weights of the variables predictive of the classification equation indicate differences between the groups (Figure 3).

The levels of $\mathrm{Mg}, \mathrm{K}$, and $\mathrm{N}$ were higher in Mombasa grass under $25 \%$ and $50 \%$ shade and full sun in the four cycles in order of decreasing magnitude (Table 3).

Table 3. Discriminant function classification coefficients.

\begin{tabular}{ccccccccc}
\hline & & $\mathrm{Ca}$ & $\mathrm{Mg}$ & $\mathrm{K}$ & $\mathrm{P}$ & $\mathrm{N}$ & $\mathrm{MS}$ & Constant \\
\hline \multirow{5}{*}{$2^{\text {o cycle }}$} & MSP & $-9,26$ & 32,42 & 8,02 & 63,07 & 8,74 & 0,015 & $-268,425$ \\
& $\mathrm{M} 25$ & $-15,11$ & 41,31 & 8,92 & 51,34 & 8,23 & 0,014 & $-251,936$ \\
& $\mathrm{M} 50$ & $-14,10$ & 39,39 & 7,97 & 52,17 & 8,56 & 0,010 & $-240,648$ \\
\hline \multirow{3}{*}{$4^{\text {c cycle }}$} & MSP & $-12,83$ & 25,78 & 6,41 & 58,56 & 10,00 & 0,011 & $-248,614$ \\
& M25 & $-24,65$ & 31,32 & 9,30 & 53,50 & 11,11 & 0,010 & $-297,403$ \\
& M50 & $-19,79$ & 31,92 & 7,90 & 45,58 & 8,01 & 0,007 & $-194,324$ \\
\hline \multirow{3}{*}{$6^{\circ}$ cycle } & MSP & 2,16 & 22,41 & 4,12 & 33,18 & 5,78 & 0,006 & $-95,1515$ \\
& M25 & $-13,72$ & 36,88 & 7,13 & 37,85 & 7,51 & 0,011 & $-182,350$ \\
& M50 & $-13,98$ & 29,19 & 7,61 & 32,15 & 7,16 & 0,007 & $-149,673$ \\
\hline
\end{tabular}

continue 
continuation

\begin{tabular}{rrrrrrrrr}
\hline & MSP & 12,65 & 30,60 & 7,44 & 51,52 & 7,82 & 0,024 & $-240,726$ \\
& M25 & $-31,73$ & 43,30 & 8,35 & 59,36 & 10,33 & 0,016 & $-325,247$ \\
$7^{\text {o cycle }}$ & M50 & $-18,99$ & 36,86 & 7,67 & 48,17 & 8,57 & 0,013 & $-229,177$ \\
\hline
\end{tabular}

Percentage of correct classification of the model: $91 \%$. n: Non-normal distribution. Scores of the other variables disregarding Ca of the variance structure. BSP: Marandu full sun, B25: Marandu 25\% shade, B50: Marandu 50\% shade, MSP: Mombasa full sun, M25: Mombasa 25\% shade, M50: Mombasa 50\% shade. Normality Shapiro Wilks 5\%.

For each discriminant variable, the explained variability was $48 \%$ for the first variable and $31 \%$ for the second variable. Therefore, the characteristics of the groups were relevant for separating the group in different dimensions (Figure 3).

The discriminant analysis allowed identifying five different groups, including MFS second cycle, MFS sixth cycle, MFS seventh cycle, M25 fourth cycle, and M25 seventh cycle (Figure 3 ).

Among the evaluated groups, treatment M25 in the fourth and seventh cycles and MFS in the second, seventh, and fourth cycles could be distinguished from the other cycles, indicating a higher external influence on the variables that compose the discriminant factors.

Considering that $\mathrm{Mg}, \mathrm{P}$, and $\mathrm{N}$ were the most significant elements for discriminating the groups, and reiterating the sensitivity of these elements under abiotic conditions, the variability in their concentrations may cause perturbations in the linear relationships between the discriminant factors and the variables involved. However, only the predictor variable DM was more homogeneous, resulting in a lower discriminant power. Therefore, even DMP, which presented a high variability in the first and last cycle between treatments M25 and MFS, does not evidence that this variable is a good discriminant predictor.

Figure 3. Scatter plot represented by the canonical dispersion scores of the most representative variables for discrimination $(\mathrm{Ca}, \mathrm{Mg}, \mathrm{P}$ and $\mathrm{N})$. Upper box to the right of the figure indicates the discriminant variable best related to the group. 1D: 1st discriminant variable and 2D: 2nd discriminant variable.

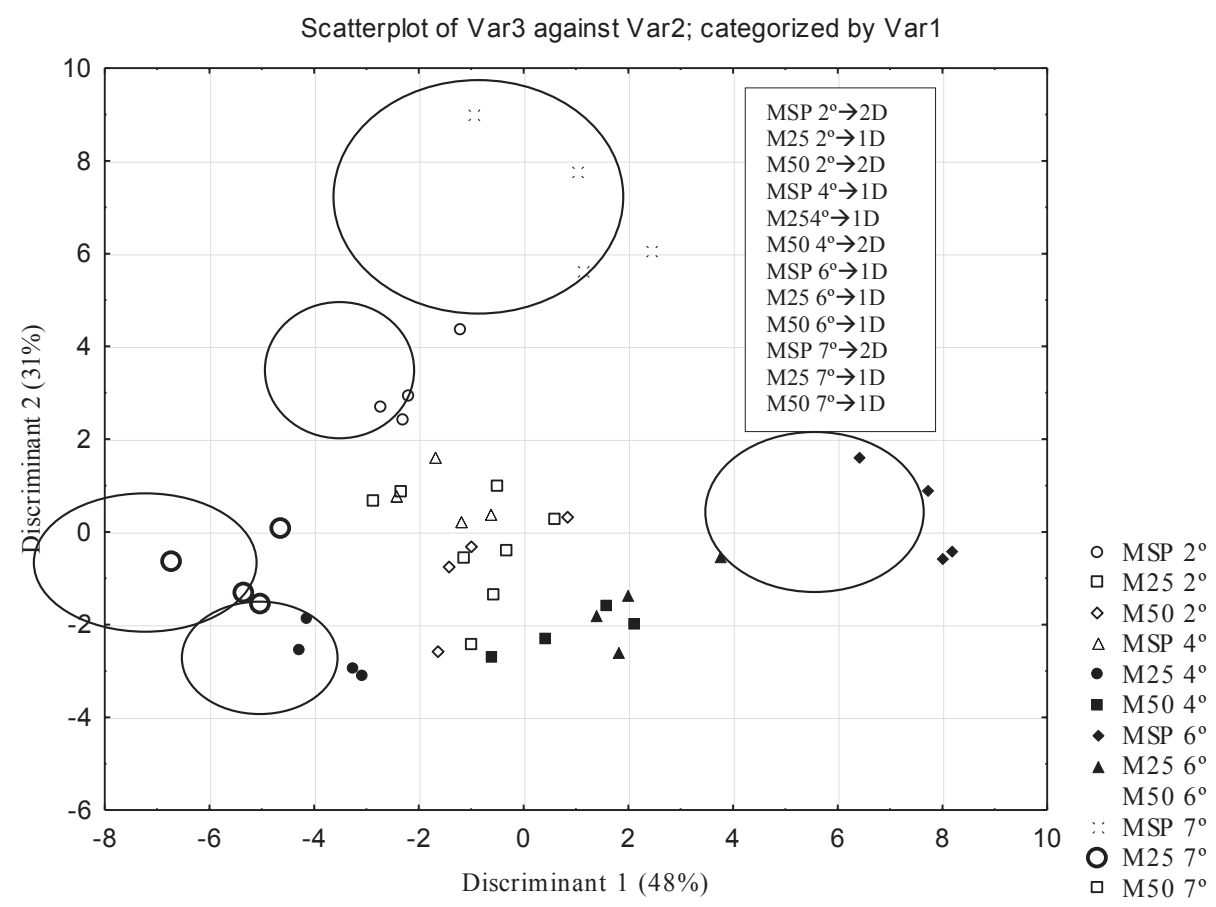


MFS was similar in treatments M25 and M50 in the rain-dry transition season (cycle 6). However, MFS in cycle 6 was significantly different from the other two treatments, which is consistent with the results shown in Figure 3.

The highest concentrations of $\mathrm{Mg}, \mathrm{K}$, and $\mathrm{N}$ in plants grown under shading, especially in treatment M25, indicates that this treatment is better nutritionally.

$\mathrm{Ca}, \mathrm{Mg}, \mathrm{P}$, and $\mathrm{N}$ had the highest sensitivity to shading. These elements help identify productive forage plants of high nutritional value under shading conditions. $\mathrm{Mg}, \mathrm{K}$, and $\mathrm{N}$ are good qualitative variables for use in classifying Mombasa grasses under different shading conditions. In contrast, DMP has a low classificatory potential, evidenced by the low values of its coefficients.

The lack of analogy between the two conditions demonstrates the need for more studies on the use of livestock-forest systems to assess the compatibility between species that combine high production of biomass and high production of nutrients.

\section{References}

ALMEIDA, J. C. C.; ROCHA, N. S.; NEPOMUCENO, D. D.; ARAÚJO, R. P.; SILVA, T. O.; MORENTZ, M. J. F.; ABREU, J. B. R.; CARVALHO, C. A. B.; MACEDO, R. O. Composição mineral de leguminosas forrageiras cultivadas sob diferentes níveis de sombreamento. Semina: Ciências Agrárias, Londrina, v. 36, n. 1, p. $367-$ 376, 2015.

ARAÚJO FILHO, J. A.; CARVALHO, F. C.; GARCIA, R.; SOUSA R. A. Efeitos da manipulação da vegetação lenhosa sobre a produção e compartimentalização da fitomassa pastável de uma caatinga sucessional. Revista Brasileira de Zootecnia, Viçosa, MG, v. 31, n. 1, p. 1119, 2002.

BASSO, K. C.; CECATO, U.; BARBEIRO, L. M.; LEMPP, B.; GOMES, J. A. N.; LUGÃO, S. M. Influence of nitrogen levels on leaf anatomy and nutritive value of millennium grass. Bioscience Journal, Uberlândia, v. 30, n. 3, p. 792-802, 2014.

CAMPOS, K. A. Função discriminante de fisher como alternativa à análise de variância multivariada. Lavras:
Universidade Federal de Lavras, 2012. 106 p.

CASTRO, C. R. T.; GARCIA, R.; CARVALHO, M. M.; FREITAS, V. P. Efeitos do sombreamento na composição mineral de gramíneas forrageiras tropicais. Revista Brasileira de Zootecnia, Viçosa, MG, v. 30, n. 6, p. 19591968, 2001.

CIOTTA, M. N.; BAYER, C.; ERNANI, P. R.; FONTOURA, S.M. V.; WOBETO, C.;ALBUQUERQUE, J. A. Manejo da calagem e os componentes da acidez de Latossolo Bruno em plantio direto. Revista Brasileira de Ciência do Solo, Viçosa, MG, v. 28, n. 2, p. 317-326, 2004.

COELHO, J. S.; ARAÚJO, S. A. C.; VIANA, M. C. M.; VILLELA, S. D. J.; FREIRE, F. M.; SANTOS BRAZ, T. G. Morfofisiologia e valor nutritivo do capim-braquiária em sistema silvipastoril com diferentes arranjos espaciais. Semina: Ciências Agrárias, Londrina, v. 35, n. 3, p. 1487-1500, maio/jun. 2014.

COLE, D. W.; RAPP, M. Elemental cycling in florested ecosystems. In: REICHLE, D. E. (Ed.). Dynamic properties of forest ecosystems. Cambridge: Cambridge University Press, 1980. p. 341-409,

EMPRESA BRASILEIRA DE PESQUISA E AGROCUÁRIA - EMBRAPA. Manual de laboratório: solo água, nutrição vegetal, nutrição animal e alimentos. São Carlos: Embrapa Pecuária Sudeste, 2005. 334 p.

ERIKSEN, F. I.; WHITNEY, A. S. Grow tha and fixation of some tropical forage legumes as influence by solar radiation regimes. Agronomy Journal, Madison, v. 74, n. 4, p. 703-709, 1982.

FERREIRA, L. M. M. Sistema agroflorestal é alternativa sustentável para produção rural. Jornal Folha de Boa Vista, Boa Vista, 27 jun, 2005. p. 1.

GOBBI, K. F.; GARCIA, R.; GARCEZ NETO, A. F.; PEREIRA, O. G.; ROCHA, G. C. Valor nutritivo do capim-braquiária e do amendoim forrageiro submetidos ao sombreamento. Archivos Zootecnia, Cordoba, v. 59, n. 227, p. 379-390, 2010.

LAJÚS, C. R.; MIRANDA, M.; SCHEFFER-BASSO, S. M.; CARNEIRO, C. M.; ESCOSTEGUY, P. A. V. Leaf tissues proportion and chemical composition of Axonopus jesuiticus x A. scoparius as a function of pig slurry application, Revista Ciência Rural, Santa Maria, v. 44, n. 2, p. 276-282, 2014.

LARA, M. A.; PEDREIRA, C. G. S. Estimativa da assimilação potencial de carbono em dosséis de espécies de braquiária. Pesquisa Agropecuária Brasileira, Brasília, v. 46, n. 7, p. 743-750, 2011. 
MEURER, E. J. Potássio. In: FERNANDES, M. S. (Ed.). Nutrição mineral de plantas. Viçosa, MG: Sociedade Brasileira de Ciência do Solo, 2006. cap. 11, p. 281-285.

MONTEIRO, E. M.; BRASIL, E. C.; LOURENÇO JUNIOR, J. B.; BARROS, C. S. Massa de forragem e composição químico-bromatológico de Panicum maximum cv. Mombaça adubadas com resíduo de siderurgia, nitrogênio e fósforo. Agroecossistemas, Belém, v. 6, n. 1, p. 74-96, 2014.

NOGUEIRA, A. R. A.; SOUZA, G. B. Manual de laboratórios: solos, água, nutrição, vegetal nutrição animal e alimentos. São Carlos: EMBRAPA Pecuária Sudeste, 2005. 334 p.

NUTRIENT REQUIREMENTS OF BEEF CATTLE - NRC. Mineral requirements and maximum tolerable concentrations. $7^{\text {th }}$ ed. Washington: National Academy of Science, 2000. 242 p. (Nutrient Requeriments of Domestic Animals, 4).

RAO, I. M.; SHARP, R. E.; BOYER, J. S. Leaf magnesium alters photosynthetic response to low water potentials in sunflower. Plant Physiology, Glasgow, v. 84, n. 4, p. 1214-1219, apr. 1987.

SCARDELATO, J. A.; LEGRAMANDI, V. H.; SACRAMENTO, L. V. S. Ocorrência de cristais em plantas medicinais utilizadas no tratamento da nefrolitíase: paradoxo? Revista de Ciências Farmacêuticas Básica e Aplicada, Araraquara, v. 34, n. 2, p. 161-168, 2013.

SELLE, G. L. Ciclagem de nutrientes em ecossistemas florestais. Bioscience Journal, Uberlândia, v. 23, n. 4, p. 29-39, 2007.

SILVA, D. J.; QUEIROZ, A. C. Análise de alimentos: métodos químicos e biológicos. 3. ed. Viçosa, MG: UFV, 2002. $235 \mathrm{p}$.

SILVEIRA JÚNIOR, O.; SANTOS, A. C.; RODRIGUES, M. O. D.; RODRIGUES, M. O.; ALENCAR, N. M. D. Produtive efficiency of Mombasa grass in silvopastoral system under pasture deferment and nitrogen fertilizer. Semina: Ciências Agrárias, Londrina, v. 38, n. 5, p. 3307-3318, 2017.

TAIZ, L.; ZEIGER, E. Fisiologia vegetal. 4. ed. Porto Alegre: Artmed, 2009. 848 p.

VITTI, G. C.; LIMA, E.; CICARONE, F. Cálcio, magnésio e enxofre. In: FERNANDES, M. S. (Ed.). Nutrição mineral de plantas. Viçosa, MG: Sociedade Brasileira de Ciência do Solo, 2006. cap. 12, p. 299-322.

YADAV, R. P.; SHARMA, P.; ARYA, S. L.; PANWAR, P. Acacia nilotica-based silvipastoral systems for resource conservation and improved productivity from degraded lands of the Lower Himalayas. Agroforest System, Netherlands, v. 88, n. 5, p. 851-863, 2014. 